Nome District................. 3

Bolomon District ................ . 13

Casadepaga D1strict. . . . . . . . . . . . 17

Bluff District.................. 19

Counc1l District ............... 19

Koyuk D1str1ot . . . . . . . . . . . . . . . . 21

Cendle Distriot.................. . . 25

Inmachuk D1str1ct. . . . . . . . . . . . . . .31

Kougerok District. . . . . . . . . . . . . 33

Iron Creek - American Creek - District. . . . . . 37

Nulato District. . . . . . . . . . . . . 41 
U. B. OLOLOCICAL BUFVEY

RECEIVED

JAN $4-1930$
Ti1 rb: nke, 1laske

Dooumber 28, 1929

Mr. N. I. T1man 1 ar, JONEAC. MLAEKA $420 \frac{1}{3}$ North Goneged st. Los ingoles, Celip.

Dent Pimmler:

I am malling pou horewith onologod a report on plyoer mining conditions on Sownsd Poninsula. I heve triod to follow In this roport your roport of 1926. Plongo alter it ag you beo flt in order to inolude it in gour genernl report on 4 agks for 1929 .

Your lottor of Dooember 17, 1929 , has Juet boen rooofved. 1st, es to the informition regarding tho. I rull od you thig information about 10 dags ago. You ahould hevo $1 \mathrm{t} \mathrm{by}$ th1s timo. 2nd, in ragera to my raporte on the Chinanlar. Ruby and Innoxo Dfotriots: I wes in Ruby thio aumier when returning erom Nome and phij. there guthered quite a lot of deter on the Ruby and Innoko Digtrjotf. I wrote this up in ropert

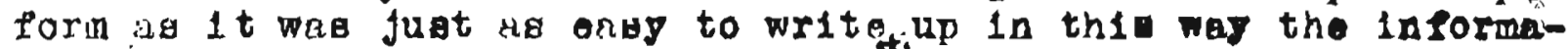

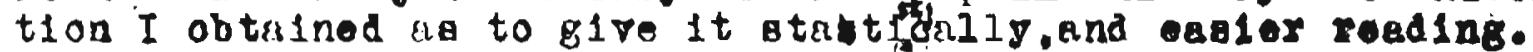
I intended the information for jour use to do with os gou saw 11t. 3rd: Jeke Fowell quit h1g underground mining rometine in November. Ho egld the ground went below 50 oents a foot wo stopped and begen drilling for better valus o. I tola nim I wantoll to got rome cost data but inve not been ablo to find him sinoo. Thoro 1 a rumor around torn that his mon aro otill unpeld. A soon a Howell oomeg in tomn agein ind I ond get oome no no int formation. I w111 writo you $a 11$ the detallo. Hy private opinion and from what I oan gathor about town 1 g that the projeat is a fillure. Thoy woro unablo to use tho olameholl as plamed and hnd to relg on the 1 ou. yd. golf dumping buoket (as I think I wrote gou before). I really think, however, that the cobice hag great poesib111t1eg and und er proper managonat oonda be worked out.

Hoplng you and youre had a very Horry $x$ an a happy How Yoar, I am, 
Mr. B. D. Stewart,

Sup erviolag Mining Englneor, Junear, Alakka.

Dear Mr. Stowart:

I am malling you herowith enclosed a report on the placer mining conditione on Seward peninsule. I will submit a report to you also on the lode mining in the chandalar and on soward Poningula.

Hoping you and your family had a very merry ymas, and a happ New Yoar, I $\mathrm{em}$, 


\section{BEPORT ON MINING CONDITIONS ON SEWARD PENINSULA FOR 1929}

The mining area herela desoribed is embraced in all thet part of Aleske IJ1ng woot of tho valieya and tributariog of the Buokland and Koyuk Rivers. For convenience, the placers of the ongalik Rivor, south of Norton Bay and outgide of soward Poningula, axe roportod along with this area. The area eltogother has had a recorded production of over $\$ 90,000,000,00$ in about thirty-one goer lagt ton joarg there has been a continuous and marked declino inspite of the large soale operations of ono oompany. The produotion in 1929 was $\$ 1,163,182.00$. Tho this was in exoese of the 1928 produotion by approximately one-half militon dollars. still the genoral curve of produotion 18 markedig falling. The highex production in 1929 was duo to a very favorable seaconal water eupply ana to the oxcoptional yardego drodged by a largo mining oompany. The disuse and obliteration of trailo and roads, the closing down of stores and roadhoues and the lack of conveyances of any kind, has so raisod freight rater thruout the interior of the Poningula that the miner has to have very good ground in order to mako his mining activities paj.

Frelght rates to lome from seattle and general prices thexo have remainod the seme in the last four or five goars. They were oovered fully in the 1926 report of Mr. N. I. Wimmler. Aleo the longth of soasons and othor general aata such as moens of transportation, fuel supply. labor, wageo, otc, have been given so fully In the aforesald report and the various reports of the U.S.G.S. that they wil not be repeated nere. However, since 1926, the extension of aeroplane travel to the Peninsula has covered it with a network of alrlines. Where. formorly it took daye and even reoke 
Soward Peninerala Ro it it -2-

to get Irom one part of the Pensnsule to another, now almost every town in it oould be visitod in two dayg flying. This groatly fac1litates businese and the distribution of ma11. However, it does not holp gonoral mining to ang great oxtent as prelght rates by aeroplane are et1li too high to ahip staplos by this means. Neroplane lanaing fields hove been bullt or lalả out at Nome, Canôle, Deoring, Telier, Lost Rivor, Cape Prince of Wales, Taylor Creok (Kougarox), Krargamepe Hot SpringB, Solomon, Council, Bluff, Chinik and Dime Crook.

Radio communioationa are not in such a good condition. There 10 a $U$. S. S1gnal Corp. radio atation at Nomo and another at peilor. Cande has a privately owned radio station which is not now in use. Nome, Solomon, Bluff, Chinik and councli are conneoted by a rather prooeriou tolophone line. This line elso extended formerly to Candie, but this ond of it lo gt present out of oommission. Candle and Deering are algo conneoted by telophone line, are also Candile and Keowelik. These work intermittently when eomeono happens to walk along the line and is kind onough to temporarily braco the wire off the ground. There is also a telephono line between Nome, Sholton and Kuzgamepa Hot Springs. Soward Pentasula at one time was crossed by a network of telephono lines. These have been allowed to fell into aisuse except the above mentioned. They will not pey for aintenance by private enterprise. Thru the publio spiritness of the Iomen Relndeer and Trading Corporation and other ownors of reindeer. the miners are kllowed to kill their own meat from the numerous herds of reinder which evergwhere cover the peninsula. The only stipulation 18 that they bring in the marked oars of the animals so taken in order that the orlginal ownera mag bo ascortained 
and pay be made for the animals at the rete of $\$ 20.00$ a hoad.

Mining on Sowera Peningula 1a confined to dredging, hgdraw10king and chovoling in. Also a littlo drift mining is still going. On aocont of the high oost of fual and the greater adeptability of the oreoks to hydraulloking, the moohanioal goaper plant, oo oommon in parto of the Intorior, is non-exigtant oroopt in two or three inotancos. In 1929 there were 319 men ongaged in or about tho operatione of 13 dredge日, one of wh10h was in the oourgo of construotion; 132 men in 31 hydraulio operations, $\nabla$ mon in 4 arift mine operations, 6 men in one soraper plant oporati on and 69 mon in 60 novelling-in operations. There wre 50 men ongaged in 15 progpooting operations. Besides these thore woro 12 men prospocting on lode tin, 5 men prospeoting on entimong and gold lodes, and 2 men on a oinnabar prospoct.

$$
\underline{N} \underline{M} \underline{\underline{E}} \underline{\underline{I}} \underline{\underline{S}} \underline{\underline{R}} \underline{\underline{I}} \underline{\mathrm{C}} \underline{\underline{T}}
$$$$
4+5^{2-42}-\text { DREDGING }
$$

THE BAMMON CONSOLIDATED GOLD FIEIDS, a Bubaidiary of the U. S. Snelting. Rofining and Mining Co.,18 oporating 3 olectrioally driven dredger on the tundra (3rd beach lino and Monrooville beach line) 3 miles north of Nome. A fourth dredgo was formorly operatod on snake River about $I$ m1le west of Nowe at the mouth of Center Creek but was dimantled in 1927. The日e arodgea are known a No. 1, No. 2, No. 3 and No. 4 ( on Snake Riverl respeotively. These arodges were describod in dotail on page 94 in the 1926 report of Mr. N. I. Wimmler. An average of 200 men are emplogea altogether.

The same methods of spacing the points and olzes of points for cold water thawing were used in 1929 as described on page 15 of the aforesaid 1926 report. CEvery thirteonth $3 / 4$ inch pipe in the center of 12 thawing p1pes arranged in 2 ooncentrio eoullateral triangles, one contalning 3 plpes and one 9 plpos, 16 sealed or plugged at the bottom. 
It 10 Ulol al tomporature teat plpe for the blook of ground containod in the largor equilateral triangle. The ground io tegted by a resiatance thormometer lowered down the tost pipe by heavily insulated oopper wiros. The we wres are attaohed to a battery and galvanometer reoording degreos farenholt. Tooting for frost is dono overy 5 ft. down from the surfoco. The arerage time allowed for thawing with $3 / 4$ inoh pipo points 1 about 70 daga, and w1 the 1 1/2-inch pipo pointe about 135 dege (or a fuzI segeon). Howerer, some points aoguiro water for moro then one sosson. The efflolonoy of the water as a thawing agent increases very rapialy with a rlaing tempersture. Thus water at $55^{\circ}$ to $65^{\circ} \mathrm{F}$. 18 more than twioe a efficiont a wator at $4^{\circ}$ to $55^{\circ} F^{\circ}$. Where thore are much sol1d in the muck, short ewerters are somtimes put down to thaw it. Hewevor, the muck 19 genorally so largely composed of fce that most of It run off with the water. The $1 \mathrm{ft}$. to $2 \mathrm{ft}$. of mose at the surfaco 18 loft Inteot and serves to koap the ground from freozing back in the winterg after boing thawed. Ten foot lengths of $3 / 4$-inch pipo are ueod in driving and the pipe 1s XX in woight. Tho pipo points are attachod to the hoe by a short curved piece of pipe known as a "gooseneck." The pipes Bink rapidly with little effort thru the muok but have to be driven thru the grave. The oompany has doveloped special Elampa and sloovemhamore for this purpose. The company has about 75 men working on the thawing. Water is furnished by tho liooehe, pioneer and Wild Goose ditohes and pumps doscribed on page 96 of the 1926 roport. About 25 men are employed on the ditches. Drodge No. I is working wost in the "glough over" of the 3rd boech line about on the Kartin Bench olalm. No. 2 1s worising weet in the Monroovilio beeoh and 3rd boeob "sloughover" about on the Mystery Bench Claim near I1ttlo Creok. No. 3 is working north above 
above the 3rd boach at the head of I1ttle Creek about on No. 2 hbove Iftile Creot Clalm. No. 2 will dredge from 1 tg present locktion back to the tramlino traok and will bo finishod in the sumper of 1930. It will thon be digmantled and haviod to noar the mouth of center creok on Snake River ground jugt north of Snake River by old Dredge No. 4. The ground is now boing thawed in this now area and a road bulld paralloling the tramline from Iittio creek to sake River. The dredge will gtart digging at the old Wild Goose Dam on Center croek fuat above the trams: line. No. 3 will oontinue to work north and eagt towara cooper Gulch from ite pregent location. The ground hero 1s gotting ghallower and the dredgo pond bocouse of mang gullies cut by provioug hydraulio operations in tho muok and top gravel, hard to hold exoopt by extengive drax daming. Thero is about 3,000 horsepower avallable from the six 525-H.P. Paclfio Diesel Wexkspoor enginos. The full oapaolty 18 roquirod only when tho thaw pumpa are running. The aggregate roquirement for the dreages is about $2000 \mathrm{H} . \mathrm{P}$.

Tho 3rd boach lino has boen dredged as far oat 88 Holyoke Croek where the ground beome too doep to handle, $85 \mathrm{ft}$. being the meximum for these drodges. Where the ground has boon drifted, onpoo1ally whero it was low grado, it will not pay to drodgo. somo diatanoo abovo bedrock in the gravel on the 3rd besohlino was an untouched payatream whloh sorved to onrioh and make pag by drodging the perte of the 3rd beach that had been drifted out. If no ohoaper methode axe found to hand ground, tho lifo of thig operation at Iittlo creok is only a fow yearg moro. The Iffo of tho operation at conter croak may last longor but it 19 doubtful whothor it would peg to run one aredge after the other two aro shut down. All threo dredgos, taking into aooount shut-downe and olean-upe, averagod in the serson of 2929 botter than 
8000 oubic yarda a day. This record is due to tho orroful proparation and thewing of the ground, for atleast 2 yoars ahead of tho dredges. About 40 men altogether aro omployed on the droages. This oompany has put dredging in the Nome Diotrict on a solentific and pratical basis. Any compaing or porson oontemplating drodging in Nlagka should study their methode. Eapocialiy interogting are tho method thoy havo devolopod for handing thawing points and thew1ng the frozen ground; the Fratod drume on tho fordion traotors uged in omnootion with omall glip soraperg to butld dame for drodgo ponde, and the Wost cable Grip (manufactured in Portland, Oregon) usod for ghifting the arodgo linog. In order to show posalble length of dredging season in the Nome Distriot, tho followlng starting and ghuting down dates for the sogson of 1929 aro glven:-

\begin{tabular}{|c|c|c|c|c|}
\hline Dradge No. I & start & May 27 & shut down & ootober \\
\hline Drodge No. 2 & $n$ & May 18 & $n$ & ootober \\
\hline Dredge No. 3. & v & May 22 & $n$ & ootober \\
\hline
\end{tabular}

b THE LOMFN REIINDESR AND TRADING CORPORATION aro operating a dredge on

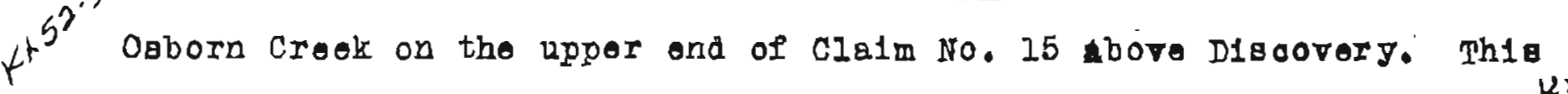
dredgo wag formerly oporated by the ame oompeng on solomoh River. It Is degoribed in dotali on Page 101 of the 1926 report of Mr. I. I. Mimmler. The mabinory, largo timberg and power plant war moved from Solomon in the eumor and winter of 1928. A now huld wao bu1lt at the prosent loogtion of the eamo dimeneions as the old. All parts of the new hull and ahtnery and power plant are the gamo oxoept a 4-ft. overhang of the houalng on oach side of the dredgo has been oliminated. The ghaking goroon and no gavo-all fogturos of tho old dredge have been rotalned. Tho power plant got-up 10 much more roomy and bettor then that at Solomon. The ground formerly bolonged to Ieo and swenborg, who 
Seward Peningula Ro: it $\quad-7-$

took out elovator pita both bolow and above whoro the aredge ie now work1ng. The bodrook 1e very uneven, dopths of gravel ranging from 4 ft. to $12 \mathrm{ft}$. The ground is all thawed and there is practicaliy no overburden. Where the drodge is at present a clay bedrock causes difficultios in saving the gold. On No. I6 Above Discoverg sohist bedrock ocours and no more trouble in eaving the gold is antiolpated. The right limit bonohor are oxpooted to dredgo vory woll. In two outs into the bench by Loo and Swenborg abovo tho dredgo and in a cut into the bonoh bolow tho dreago by a former oporator, vory good money la gald to havo been taken out tho bedrock was not reachod. Tho bodrook in the upper cuts pitohes downward into the benches from the rim of the prosent crook bea. I small orow of men 18 doing experimental hyaraulicking to teat out the bonohes. Water is furnishad by an 8-mile ditoh from uppor osborn Creok oarrying about 500 miners inches at a hoad of about 165 et. at No. I5 lbove Discovery. The dredge sterted work on July 17, 1929 and wag shut down for the geg8on on 1929. The rated copec1ty is about 3500 ou. yards a day. Tho sotual algging eo far has avoraged about $2000 \mathrm{cu}$. jdg. a day. The company owns outr1ght about 600 acrea and has under option about 200 acres more. If the ground prover up as expocted, the life of the operation is expocted to be over 25 years. 21HE BANGOR DREDGING CO. Plniohod operating thoir $21 / 2$ ou. ft. buoket dredge on Auguet 16. 1929, on the upper ond of No. 10 Above D180overy on Anv1l Crook. The dredge started work for the seaton on July 1, 1929, and averaged about $2000 \mathrm{cu}$. yda. Of digging a day. 9 mon woro omployed incluaing a cook and a managor. The dotalis of the drodge 1 tgelf aro given on page 95 of the 1926 roport. Anvil crook ha nor boon dredged from tho lower ond of D1 soovory to the uppor end of ro. 10 Abovo. 180 THE DRY CREFK DREDGING CO. 19 operating a arodge on No. 3 BeIOT D10covery on Dry Crook. Thle drodgo has 3 ou. It., 010 so connooted buokete 
dumping at the speod of 25 por minuto. The hull $1866 \mathrm{ft} . \mathbf{x} 28 \mathrm{ft}$, and $5 \mathrm{2} / 2$ t. deop. The dredgo 19 a stralght flume typo. The flume is 72 ft. long and 32 1nches wide, set on a $10-1$ nch to $12 \mathrm{ft}$. grade, and fitted with trangergo manganoge rall rifilog. No undorcurront 18 used. Power 19 supplied by an 80-H.P. Venn-Soverin Diesel Ingine. The dredge averages $2200 \mathrm{cu}$. yda. digging a dag. 2 outs, ogoh 180 ft. Wido, are tak on in tho orook. The ground avorager about $12 \mathrm{ft}$. doop to a false olay bodrook and is all thawed. The winter frost on the aurfaos ts thawed by the oold water thawing mothod for about 4 weaks whon f1rat starting in tho oping. 8-ft. pointe ariven at 6 ft. oontor aro ueod. The avorggo geason 19 about 100 daga. 5 men are employed. Thia undoubtedly is tho mogt cheaply operated drodgo in slagka. Ground avoragIng 6 oonts a cu. yd. may bo dredged at a slight margin of profit. The gold 18 worth $\$ 18.40$ an ounoe and is modium fino. The ground 10 leased Prom the Hammon Consolidated Gold Flolda. There 1s about yoar work left on the oreek. In 1929 the drodge wa foroed to hat dom on Soptember 7 beoarge of a litigation between the above oompang and $\mathrm{E}$. R. Powe11. More detalled dosoription of this dredge is given on page 96 of the 1926 report of Mr. N. I. Wimmler. $.2^{\circ}$ TEE HASTINGS CRFPK DREDGE 00 . 18 remodeliling the old Androw Andercon dredge which was orlginally bullt on Mose Guloh and moved to Beatlnga Creek about 1915. It was formerly a staoker type rua by diatillat. power. The hull 1 s $66 \mathrm{ft}$. by $30 \mathrm{ft}$, and $5 \mathrm{l} / \mathrm{R} \mathrm{ft}$. deop. The drodgo 10 wa boing chenged to a stralght flumo typo and an 85 R.P. Vonn-geverin Diegel Ingine 1notallod. Tho digging ladedr will be longthoned and ou. It. buckete put on a close connootod bucket 1180. The arodge is on No. 5 Below D1800very. It will dredgo downgtroam meing oute, oroh about $150 \mathrm{ft}$. wide. The ground is thawed. Thero 10 abont 6 jears 
work ahoad of this arodgo. Construotion mili bo finlshod in 1930. 4 men wore employed in conetruotion.

OPEN CUT MINING -- SLIPSCRAPERS

7' soraper about $1 / 4$ mile oast of th ofty limits of Nomo and about $200 \mathrm{et}$. baok from tho beach. The ground 18 frozen and is about $18 \mathrm{ft}$ doep. The pay lieg on a falso bedrock whlch is gbout 18 inohos in elevation abovo mean high tido. The ovorburden 1 g ground alulcod off to within 2 or 3 ft. of bodrook, then gdrapod into tho boxos. The pit has very poor dralngge beoque of the elight elovation of bodrook above sea level. Much diffloulty 1s oxporlenoed in soving the gold this yoar on sooount of olay in the and. In the former 3 yoara of working tho aand was mooh cleaner. It 1a hoped by this pit to tost the ground for dredging. Begldes the omners, from one to 5 mon are employed.

\section{BYDRAULICKING}

$5^{1}{ }^{109}$. C. STEWART AND R. S. STEWART are hydrailicking in the orook bod of Monument Crook. Tho ground $1 \mathrm{~s}$ from 12 to 33 ft. doop. Thero 18 only about 1 ft. of muck over tho gravel wh1ob is coargo and containa modium sizod (up to 18 inohos in d1a.) bouldors. The bodrook 1s gohtst, but lower down the oreek, In the lower ond of the $1928 \mathrm{pit}$, a limo root

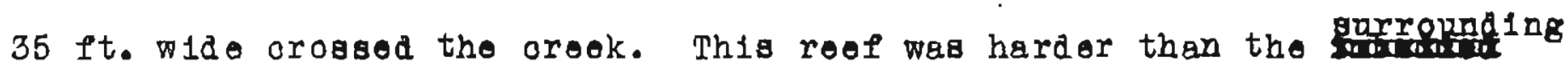
schlat and caused a gmall canyon in the orook whore it orogses. About $400 \mathrm{ft}$. from the crook on tho loft 1 imft and about 75 It. abovo it in olovation, a bench channel hag been worked out by former operators. Thia channol onded about where it crosere the Ilmogtone roof. Tho channel ovidently gwang from here to the south and towards the crook and had been oroded away and slid into the prosent oreek gerving to doubly 
Soward Poningala Repe.

onrich 1t. In 1928 a plt $342 \mathrm{ft}$. by $35 \mathrm{ft}$ and averaging $13 \mathrm{ft}$ doop wa mined. In 1929 a pit $600 \mathrm{ft}$. by, $25 \mathrm{ft}$, avoraging $12 \mathrm{ft}$. doep was mined. Water is brot to this oporation erom slodgo croek about 5 mileg thru a seotion of the old snake Rivor pitch. This altoh averages about 6 ft. $1 d \theta$ and 18 inches deep and $1 \mathrm{~s}$ on a grado of about $31 / 2 \mathrm{ft}$. to the milo. Tho prosent pit has progrossod so far upstream that there 10 only about $10 \mathrm{ft}$. Pall from the ditch to the hoad of the boxes. Two 14x16-1noh 12-1t. boxes are used. They are set on a 12 to 1 or $81 / 2 \%$ grade. The tailinga re stacked by a $1 / 4$ cu. Jd. Saurman bottomloga goraper using for power an mrsted-Tordson Holet.ubout 3 or 4 inchos of tho bodrook is also put thru the sluico boxes. The golo 1s falrly ooarso (about "whzoat" glzo) and containe small nuggote up to as largex as $\$ 50.00$. The gold is worth about 弗18.55 an ounce. The conoentrates are composed of heavy, black, subangular sand mixed with a glight amount of scheolite pleoog. The ownera claim at least ton yearg work is left on the oroek. Beglies the owners, 9 men are employed.

19 PHILIP DEFONVILIE is hydraullcking on Gold Bottom creok at the mouth of S1lver Croek on No. 7 Above Discoverg. The ground is from 3 to 6 ft. deep, one foot of which is muck, the rest gravel. The bedrook 18 sahlet. The values aro diatributod all thru tho gravol but are moro conoentrated jugt above bodrock. Thero àro no valuog in the bedrook. The gold 1a fairly fine (about "mugtard geod" gize) and 18 worth $\$ 17.50$ plus an ounce. Water 19 supplied by a two-m1lo ditah from silver crook. It 1o about $2 \mathrm{ft}$. by $5 \mathrm{ft}$. In orose-gootion and oarrios about 400 minere inches. One 2 thoh nozzlo 1 s used in the talings and a 2l-1nch nozzio to pipo into tho boxes. The presarro in about $100 \mathrm{ft}$. Beglde日 the owner, 3 men ged worked on sharea.' The 1929 operation was a preliminary teat of the ground for $B$ moro exten- 
sivo operation in 1930.

LOUIS NASBINWING IND LENFY C.UULKINS are hydraulicking on Anv1l crook and Nokula Guich. Bosidos the two owners, 4 mon are eraployed. FRED BARNOFSKI is hydraulicking by himeolf on the 3rd beach gbout $1 / 2$ mllo east of Bastings Creek.

\section{SHOVEIIIING-IN}

S. SiNSOUCI is ground slulolng and shovelling-in alone juat north of the present boach about 1 mile eat of Jess Creok. CHARIFS MILIER AND IORENS WTMDEII aro oboh shoveling in on the present beach west of Jega Croek. JOSEPH NEURAUSER $1 \mathrm{~s}$ ground sluicing and shovelling in alono on Gras Gulch.

HNNRY LIRD is ground sluicing and shoveling in alone on specimen Gulch.

\section{DRIF T MINING}

JAK TOPOLSEY is drift mining alono in winter on the Right Fork of Dexter Croek. He tlso ground slujcos and shovels in in the summer. JOHN ABRAHAMSON 18 drift mining alone in winter on the 3rd bogoh about

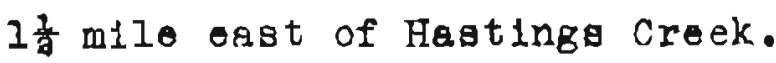

\section{PROSPECTING}

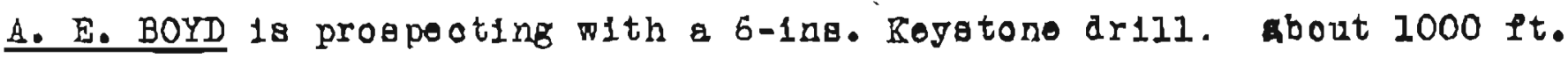
oast of the head of Iittle littlo Creok. Tho line of drill holos runs from this point northwest about $2000 \cdot \mathrm{ft}$. to Littlo creok. The aurface of the ground hero is praotlcally lovel. The dpoths of the orill bolos startod at $34 \mathrm{ft} .$, sank in the center of the line to $66 \mathrm{ft}$. , thon roso to $40 \mathrm{ft}$. The tallings from the drill holeg oontained muoh blue wud with the aand and rosembled material from tho bottom of an off-ghore lagoon rathor than from a true beaoh. In 1988 on thia ame proopeoting 
oporation Otto Halla sank a $4 \times 4$ ft. shapt $35 \mathrm{ft}$. doep at the hoad of Ifttlo Ilttze crook. There $1 \mathrm{~s}$ gald to bo 8 to $10 \mathrm{ft}$ of beach gand in this ehaft which oarrios good values in the lower 3 to $4 \mathrm{ft}$. A drift $90 \mathrm{ft}$. long was run from the bottom of the shaft. It is sald that this book line has boen outlined by drilling for a length (east and weat) of $1600 \mathrm{ft}$, and a width of $145 \mathrm{ft}$. It appears that this beachline 19 a section of a bar or spit on the outer edge of a lagoon. 1 good roed has been bullt to this prospect by the A.R.C. THE S.I.B. (STEWARD, LOBE, BOYD) DYVMOOPREN CO. is drilling on the 3rd boach west of Snake River, and is repalring the old 4-m1lo wild Goose Ditch from sunget crook. It has seoured optiong on the Berger and Sullivan ground on Frening Gulch, the Marine No. 2 Asgoclation and other ground. In 1930 the intention 18 to oross-out the 3rd beach with an open cut, using wator undor about $75 \mathrm{ft}$. fall from the aforesa1d ditoh. They will uge mechanical (Grant) talling gtaoker to alspose of the tallings.

CHAS. KENIFDY AND RELIX BRUNER are putting in a drain on tundra about 1/2 mile oegt along beach from Gillette. They are oroes-outting tho ane streak Gillette is on and intend to tost the ground for drodging by shovelling in.

H. L. BLAKE is progpecting by alnking shafte on the left limit of Cunningham crook and on the divide botwoen Cunningham crook and Grove Gulah.

CHAS. NIBBURRE 1a prospooting by alnking a shaft and drifting on the right limite of Dry Crook. CEAS. BUTLER is progpecting by sinking shafte on Rook crook. CBAS. MADSEN 1a prospooting on Buator crook.

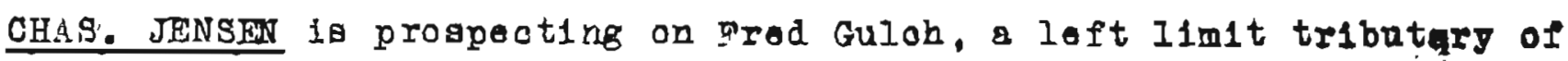


Soward Poningula Rep, ; - - I3-

Stowart River opposito Gold Bottom Creek.

JOHM"ARCTIC" SMLTH shovolled in and proapected alono on Arotio crook and Cripple RIter.

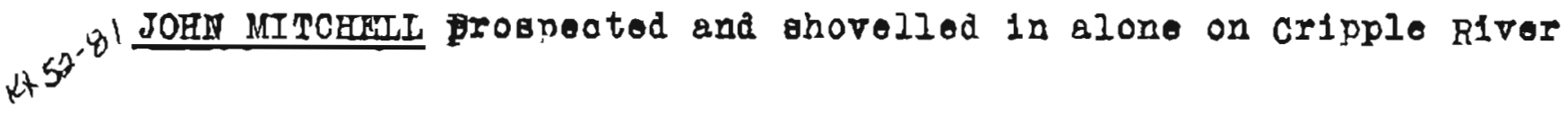

$\underline{S} \underline{O} \underline{I} \underline{O} \underline{M} \underline{O} \underline{N} \quad \underline{D} \underline{I} \underline{S} \underline{T} \underline{R} \underline{I} \underline{C} \underline{T}$

Following the 1926 report, the solomon Diatrict 1s roported eoparately from the Nome Diatriot. Freight for the solomon Distriot and the Caradopage R1ver 19 landed at the mouth of the Bonanza River. From th1 place a good road leads up solomon River. The lighterage charges at Bonanza are 10.00 to 12.00 a ton for all olagseg of eroight. The freight rate to 325.00 a ton from the beach at Bongnza to the head of Solomon River at the Goldmith Dredgo.

THE DOIDSMITH DREDGING CO. WaB operating the only arodge on solomon pt $^{3^{\prime}}$. River in 1929. The oompeng etarted aredging in the fall of 1926 at tho mouth of Coul Crook and dug up to the fall of 1928 about $13 / 4$ mileg ap Solomon River, which wa as far a it wa praotioal to dredge. Thib original dredge 1e devoribed in dota1l on page 100 of the 1926 report by Mr. N. I. Wlmmler. The hull, which wag bullt of verg light mater1al, wae etrlpped in the fall and winter of 1928 of mechinory, buokets, digging ladcer, spuds, eto. Thege were transported 4 miles down river to whero a new hull weg constructed in the early summer of 3989 . The now hulz is $70 \mathrm{ft}$. long, $30 \mathrm{ft}$. wide, and $6 \mathrm{ft}$. doep. The bucket line

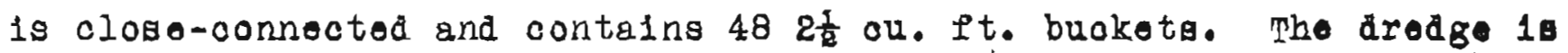
a atraight flumo typo with no lindorcurrent or gave-all. The stoel flumo is $100 \mathrm{ft}$. long and 36 inohes wide and fitted with rall riffles. Whe 
The buckets dump alrectly into head of thume. Fower is supplied by a 120 H.F. Talrbanka Morse "Y" typo sem1-diesel englne. In 1928 tho formor dredge averagea between 1800 and 2000 cu. $\$$ ds. a day, and it is prosumed thet the pregent one will average at leagt as muah. "t the prosent looetion the ground averages from 3 to 12 ft. In depth. It wil avorago, when algging farther upetream, however, about 7 or 8 ft. Thero ig no overburden on the Eravol. Which is thawed. The bodrock is schist with bands or reefs of harder linestone. The pgy lies on the bedrock and goeg into it a few inches. At leat 6 inohos of bodrook $1 \mathrm{~s}$ dug by the dredge. The gold is modium fine (about "pinhoad" size). The value is ebout which 7 have been dredged. 9 men, inclqding a cook and managor, aro employea. The season averager about 100 days.

FYDRAUIICKING

E. W. QEIGLEY is hyaraulicking at the mouth of Biga Hurrah crook on the St. Michaels Benow and Discovery Claim. Up to the Pall of 1928 a hydraulick elevator had boon used. it present he is piping over tho side of the boxeg 1nto the flume. Throe 3-1nch giantg are used, one in the pit, one in the talinger and one oppogite the pit noer the hoad of the flume whore it can bo used in both tho lowor ond of the faume and in the tallings. The flume is 4 boxes (48 ft.) lang and 3 ft. wide. A p1t 350 ft. $\times 200$ ft. bag boon minod. Water ia suppliod by a 9-m1lo ditch with an 8-ft. bottom, from tho East pork of solomon R1ver. Thero Is $210 \mathrm{ft}$. fall from tho ditch to the pit. The ground is about 12 It. doop. all thawod and with no overburden. Thore aro mang modium-alzed boulders in the gravel. The bodrock 1o sohtet. The gold I10 direotly on and in the upper bodrock. 2 or 3 ft. of bodrook $1 \mathrm{~g}$ pat thru the flume. The gold 18 falrig coargo (about rrook saltn o1so) with mang 
\$30 to $\$ 40$ nuggete. One nugget worth 700 has boen found. The gold $1 \mathrm{~s}$ worth 317.70 an ounce. Frolght from seattle to the mine costs .52 .00 a ton $(\$ 20.00$ a ton from seattio to Bonanza, 12.00 a ton lightorage at Bonanza, 20.00 a ton from Bonanza to the mine). Besidos bimself, 6 mon including a cook, aro employod. Ifter 1930 or 1931 rulglay Intonada hydraulicking below the mouth of Big Furrah on the left limit boncheg of Solomon River. Detalls of hil former operations are given on page 102 of the 1926 report of $M r$. N. I. Wimaler. JOHN DIECKMAN to hydraulicking by himgelf on B1g Hurrah Creok about 2 miles above the mouth on a fraotion botween NO. 6 and No. 7 Above Dieoovery. $\mathrm{He}$ is piping directly into a llume, working with a $2 \frac{1}{2}$-inch nozzlo und or a head of $20 \mathrm{ft}$. The ditch $1 \mathrm{~s}$ about $1 / 2 \mathrm{mllo}$ long with a 3-ft. bottom. He had just started to mine in 1929. proviougly to this he had boen putting in a 1000-ft. drain. H1s pit in 1929 is about $100 \mathrm{ft}$. Iong and $60 \mathrm{ft}$. Wide. The ground $1 \mathrm{~g}$ all thawed and about $6 \mathrm{ft}$. doep. Thore ig no overburden. There aro many bouldera in the gravel. The bedrock is schis $t$ wh theols of limestone in 1t. Tho gold is coarse and lies mostly dirootly on and in upper bodrook. JOEN MELION $1 \mathrm{~s}$ hydraulicking about $1 / 4$ milo up on willow Guloh, a smell left Iimit tributary of Solomon.River noarly opposite tho mouth of Shovol Crook. This is oridently part of an old solomon River lying botweon the head of Willaw Guloh and Moran Gulch. Mollon has hydraulis:., loked out a drain $500 \mathrm{ft}$. long by $50 \mathrm{ft}$. wide down Filion Guloh. The raok in the ohannel $1812 \mathrm{ft}$. doep at the lower ond of the drain and 29 ft. doep at the upper ond in the channel. The gravel in the ohannel 18 $10 \mathrm{ft}$. deep. There are meng bouldera of l1me, Johigt and groenstone in the grevel. The bedrook 18.sch1gt. The gold is the game alze and finoness as the solomon River gold. Water 1s obitalned 
by a g-mile aitoh with a 5-ft. bottom, from Uncle ssm creek. Tho workIng on property sino 1926, no actuli mining has yet been dono as so much preliminary lubor was required. The channel has boen thoroly prospected by sinking shafta. lbout $1500 \mathrm{ft}$. of channel is avrilable for hyöraulicking.

\section{SHOVILIING IN}

1) $N$ NDY NEUBFRG is ground sluicing and shoveling in at the mouth of Jerome Crook on Claim No. 1. He will olean a pit $300 \mathrm{ft}$. long by $12 \mathrm{ft}$. wide. The ground is all thawed and about $9 \mathrm{ft}$. deep. $7 \mathrm{ft}$. of muak and sand is ground-sluiced off and the lower $2 \mathrm{ft}$ of fine gravel shovelled in. The bodrock is schiat. sbout 4 or 5 inches of bedrook is taken up with the gravel. The gold is like beach gold, vory fino and flakg. It is worth cbout p 18.50 an ounoo. Water la obtalned for mining and ground sluiclng from the crook. Bogdiog himgolf, one man $18 \mathrm{om}-$ ploged. The average season is about 100 dags.

MORN STIRR is ground sluicing and shoveling in by himeele on wost Creok, a right limit tributary of shovol croek. Ho 18 working about

\section{$3 / 4$ mile from the mouth on No. 3 Ibove D1scoverg.}

CLIS. ANDERSON 19 shovolling in by himself on NO. 6 Bolow senoh on the left limit of Solomon River.

O. J. LuMOUNTAIN Was shoveling in and progpecting by himeelf on No. 7 Bolow Bench on the loft limit of. Solomon River. Fo quit and went out in september.

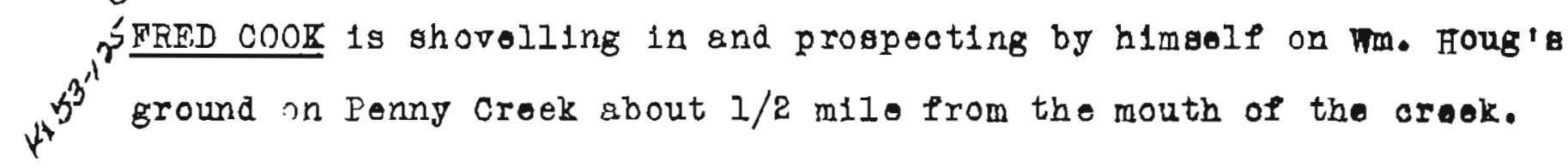




\section{PROSPFCII NG}

J. V. KanNAN with 3 men was drilling in the summer of 1929 on lower Solomon River for the Solomon Valleg Drodging Co. It is said this compang will start operating its dredge which is now idje in the summer of 1930. A full dogorpption of this drodge is given on page 100 of the 1926 report of $\mathrm{Mr} . \mathrm{N}$. L. W1mmler.

ALFRED HANSON is prospocting on Kasson Crook, a left limit tributary of Shovel Croek. Ho 18 woring about $1 / 4$ mile from mouth on No. I Above Digooverg Cla1m. LNDY FYLAN $A N D$ A. MLTTSON are prospeoting with a hand drill on shor ' Crook for the Shovel Croek Dredge Co. This dredge worked upstream to $I^{3}$ the mouth of West Creek at the lower line of No. 4 Bolow N1soovery whore it flnished in the fall of 1927.

$$
\underline{\mathrm{C}} \underline{\mathrm{B}} \underline{\mathrm{S}} \underline{\underline{1}} \underline{\mathrm{D}} \underline{\mathrm{I}} \underline{\mathrm{P}} \underline{\mathrm{N}} \underline{\mathrm{A}} \underline{\mathrm{D}} \underline{\mathrm{I}} \underline{\mathrm{S}} \underline{\mathrm{T}} \underline{\mathrm{R}} \underline{\mathrm{I}} \underline{\mathrm{C}} \underline{\mathrm{T}}
$$

Altho in the Council (now oonsolideted with Nome) Reoording Digtriot, the Cagadepagr Distriot, following the report of 1926 by Mr. N. L. Wimmler, 18 reported soparatoly. Pransportation into the Casadopaga District ia up the Solomon R1ver from the mouth of Bonenza crook. Above the mouth of East frork, the rad follow the rad bod of the old Solomon Rivor Ra1lroad, 1ll-advisedig torn up in 1917. Frolght into the Casadepaga Rlvor from Bonana ranges from $\$ 40.00$ to $\$ 50.00$ a ton in summer.

\section{DRFEGING}

THF CiS:IDRPAGA MINING CO. INC. 18 opergting a drodge on the Caradopaga River sbout $3 / 4$ mile below the mouth of Ruby crook. The dredgo was origlaslly nogr the mouth of Canjon Croek, and wes movod thenoe about $31 / 2$ m1leg to 1 ts prosent location. The dredgo 1s a tralght flamo 
typo. It has an open link bucket line with $2 \frac{1}{2}$ cu. ft. buokets dumping 17 to the minute. Tho hull is $65 \mathrm{ft}$. by $30 \mathrm{ft.} 5 \mathrm{ft}$ doep. The flumo 1930 inches wide and $72 \mathrm{ft}$. long. Power is furnished by \& $65 \mathrm{M} . \mathrm{D}$. Weatorn digtillato engine. The dredge averages stbout $900 \mathrm{cu}$. yds. a dey Tho average widh of ground aredged la about $100 \mathrm{ft}$. Tho gravel 1a all thawed and from 4 to $12 \mathrm{ft}$. doep. There is no ovorburdon. The gravel is bostly fine with a fow (mainly limestone) boulders. Tho bearock is a schist with Ilmostono roofs in it: Tho gold is fine (mustard soed" sizol, tho gotting coarser an drodge progresses up the crook. No nuggots noour. The value of the gold avorages 18.80 an ounce. men are employed lnoluding the cook and manager. It 18 the intention to work up/Ruby Crook. About 5 years work is left anead of th1s drodgo. The ground is leaged from S. M. Gaylord. C. C. Keater, Nole Nelaon and Wm. Allison. The average length of geason is about 100 dajs.

\section{HYDRIULICKING}

9. M. GAYLORD is hydraulioking into a flume on a right limlto bonoh of the Cagadepaga, River below Rover Croek. A Seuerman bottomlege sorapor 1s used to hand lo the tallings. A 2 a

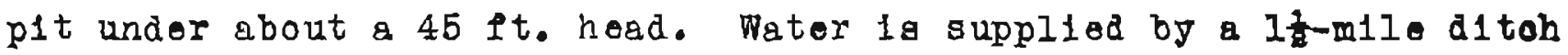
with a 3 ft. bottom. Tho ground is 12 to $14 \mathrm{ft}$. deep, with $2 \mathrm{ft}$. of gravel, the rost overburdon. It is all frozen. The gravel ia fine with no bouldora. Tho bodrook 1a schist and is about 12 It. In olovation above that in the Casadopaga River. Tho gold io diatributed threout the gravel snd does not go down into the bodrook. The gold 18 worth about 18.50 an ounco. Geglord fust roachod produotion baglat the olose of the 1929 soeson. Proparatory work was started in 1926 and oontinued to 1929 . Muoh ground has beon etripped. T men aro employed. 
bogides himself. Fo owns about 4 claims at this pince and has about 5 gearg work ahogd. Tho average mining soason is about 100 days.

$$
\underline{\mathrm{B}} \underline{\mathrm{U}} \underline{\underline{T}} \underline{\mathrm{N}} \underline{\mathrm{I}} \underline{\mathrm{S}} \underline{\underline{T}} \underline{\mathrm{R}} \underline{\underline{I}} \underline{\mathrm{C}} \underline{\underline{T}}
$$

tollowing the 1926 report of $\mathrm{Mr}$. T. I. Nimmler, this district, Which is part of the Irome Reoording Precinct, is reported separately. Placer mining operations in this district except for somo winter prospeoting, is at prosont at a standstill. The oable oxoavator plant formerly operated by the illen l:1ning co. hag boen gbandoned. The only activity cerried on in the summer of 1929 was some cinnabar prospecting which will be reported under lode mining.

$$
\underline{C} \underline{O} \underline{\mathbb{N}} \underline{\mathrm{C}} \underline{I} \underline{\mathrm{L}} \quad \underline{\mathrm{D}} \underline{\mathrm{S}} \underline{\mathrm{T}} \underline{\mathrm{R}} \underline{\mathrm{I}} \underline{\mathrm{C}} \underline{\mathrm{T}}
$$

Transportation of freight to the counoll Diotrlot is by way of tho Chinik on Golovin Bay thon up the Fish and Niukluk Rivora. Ma1l and foot travellers genersily go from Nore to councli by way of Solomon River, East Tork and Tox RIver. Loroplane gervice may now bo had from Nome to Council city. The deroplanes gonerally land on a large bar jugt below the town. A good lleld has been lald out just above the tom and conaiderable money apent on 1 t. It 1 s posalbie now to make an emergeney landing on thio field. However, with very Itt tlo furthor oxpenalture, tho rough spots could bo smoothed out and the flold put in oxcollent condition. Aoroplano faro fram Nome to Counc1l is about $\$ 60.00$.

\section{DREDGING}

THE NORTH STAR DREDGING CO, 1 o operating the flime dredge of the formor $4+n^{n}$ Northern Light Mining Co. Th1s dredge is of the stralght flume typo, distillate drivon, and with $2 \frac{1}{2}$ ou. et. buokots. It is desoribed on pege 112 of the 1926 report of Mr. N. L. Wimmler. The drodge 1 s now 
working at the mouth of ophir croek on the right limit bench opposite clatr No. 3 Below Disoovory. The company is composed of 3 partners. Mobos, Stine anâ Gumm. Inoluding thege psirtners, 8 men and a cook are employed in this oporstion. About 5 yeurs work is still lept ahead of this aredge.

Al OPHIR GOLD DREDGIUG CO. was oporating in 1929 their 3ta cu. ft. staoker drodge on No. 19 : ibove Di goovery on Ophir Creek. This drodge 1s oleotrically driven by a hydro-elootrio plant on No. 15 dbove Discovory. There is also an auxillary $160 \mathrm{~K} . \mathrm{P}$. distilinte engine for use in dry sosgong. Th1s last was not operatod in 1929. I2 men are omployed, including 3 men on the ditoh (the old Wild Goose Mining and Trading co. ditch) used for hydro-oleotrio power, one oook, one tractor drivor, one repair man and a superintendent. The company hag betwoon 6 and 10 years work left.

FYDRAUI.ICKIIIG

THOS. SHAW AND RIEX. GRACIE hydraulicked on NO. 7 hbote D1 soovery on Ophir Creek. Bostaes themselvos, 2 men are employed. This oporation will be finlshed in 1930 .

THOS. PILEIICH hyaraulicked on a bench on Albion Crook. Bogldor himgolt, one men was employed.

\section{SHOVELLING IN}

M. PETRSON shovelled in by himself on No. lis Bonoh on Ophir croez. E:RRY MATSON shovelied in by himsolf on No. 10 Bonoh on Ophir creek. NATE DIMON shovelled in by himgelf on No. 3 and $31 / 2$ Abovo Disoovery on Ophir Crook.

M. OBRADOVITCE IND MARKO MARIN shovelled in on a bonoh of swoetoake $3^{3}$ Croek. No men besides themselves were employod. $(1)^{53 \cdot}$

f5M. BROOKENS shovelled in by himaolf on Sweotceke crook. 
ROBT. LARCF shovellod in hy himself on Rock creek. ANLON HLAKONSON shovellod in by himself on Tong's Gulch, zi tributery of Welsing Croek.

FRAD. DUROCHER shovelled in and did development work on No. 1 on $\psi^{+t^{3}}$ iggie Croek, a left limit tributary of mish River about 14 miles eagt of counoil city. One msin, begldes himsolf, was employed.

$\underline{\underline{Z}} \underline{O} \underline{\underline{Y}} \underline{\mathrm{K}} \quad \underline{\mathrm{D}} \underline{\underline{I}} \underline{\underline{S}} \underline{\underline{T}} \underline{\mathrm{R}} \underline{\mathrm{I}} \underline{\mathrm{C}} \underline{\mathrm{T}}$

This is probably the rost isolated distriot of seward peninsula. Freight is transported to the aidatict by gmall gasolone-driven coastal vessels to the "Landing" on the koyuk River. Thenoo it is hauled 7 miles to Dimo creek. An aeroplane fielo was finiahed noar Hajoock in the sumer of 1929. Hereafter aeroplane travel w1ll be avallable to this mining center.

\section{DREDGING}

G. H. PFAFLE AND HORiCE POETTR Operated on No. 4 Lbove Disooverg. wag bought Irom The dredge the former Dimo Creok Dredging Co. who sold out in 1928. The machinery on this arodgo was formerly on Elkhorn Creek in the Counc1l District. Th1s machinery was moved to Dime Creek in the winter of 1923-1924 and a now hull oonetruoted in the summer of 1924. The drodgo $1 \mathrm{~g}$ of the straight flumo typo. The bucket line 1s opon link. The buokets are 1.58 ou. ft. in $91 z e, 33$ in number and dump drlectly into hoad of the flumo at a rato of 19 a minute. Power is supplied by a 25 H.P. gasolino or dietiliate engine. The dredgo is capable of diging between 12 and $13 \mathrm{ft}$. In depth. The flume is 62 ft. long and 20 inches wide. Rall riffles are used. The ground $1 \mathrm{~g} 17$ to $18 \mathrm{ft}$. doep, 9 to $10 \mathrm{ft}$. of whioh $1 \mathrm{~g}$ gravel, the rest muck. In the crook bod, it was originaliy only gbout 6 ft. to bodrook. sinoe thon the oroek has boen fllled with talinge praotionlig to the 
level of the muck banks. This creek/was originally thaw but now, owing to the filling of tailings, is all frozen. . I line rest of the ground is permanentig frozon. The bedrock is a blocky andesito I0cally known as "diortte". Lbout $3 \mathrm{ft}$ of thig bedrock is dug. The muck is ground sluiced off by the water from the creek. "rine gravel is then thawed by $3 / 4$ ihch ploe pointa driven with wooden mauls, ană spacod at the oornors of 8-ft. snuares. The points drive fairly easy as tho gravel has much ice in it and is not "tight". It takes from 7 to 8 days to comple te a thaw. Two ditches supply water. one, the hlghline ditch, is from Dime crook. It $1 \mathrm{~s} 21 / 2$ miles long and supplies water at $50 \mathrm{ft}$. prossure. The other, tho lowline ditoh, is from Fldorado Crook and supplies watter at 35 ft. pressure. The highlino ditoh oan only bo used when there $1 \mathrm{~s}$ en excess of wator from the hydraulicking on the creek above. The gold occurs in very flat, small gralng (lookg about like "Durham tobacco" in aize and shepe). No nuggets are found. The fineness is about 960. platinum occurs with the gold in the ratio of $1 / 2$ of 1 per cont of the wolght of the gold rocovorod. 5 men are employed. Those recoivo 75 centy an hour. Bestdos this amount 2.50 a day is allowed themflor boarde tillate costs 60 cents a gallon at the drodge. The drodge uses about 70 gallons in 24 hours. The drodge ran two weeks in the season of 1928, during wh th time its digeing oepacity averaged $350 \mathrm{cu}$. yde.a day. It startod work in 1929 on July 27, and quit sbout 6 or 7 yoars work is left on this operation. BYDRAULICKIITG

GEO. IFONARD IND A. W. JOBISON are hydraulicking on the upper ond of No. 5 ibove Digoovery and No. 5 Bench, Right Limit on Dime Creok. The ground is about $7 \mathrm{ft}$. doop, $2 \mathrm{ft}$. of which is graval. The 
piplag is done drecly into a flume. Two No. 2 Glants are used alternstelg in the plt and 1 in the tallings. 1-2 inch to $2 \frac{1}{2}-1$ inch nozzles are ued on the giants. Hiter is supplied by a $2 \frac{1}{2}$-mile ditch from Dime Creek under about 50 ft. pressure. Only. I shift a day is workod. Besidos thenselves, 1 man is employed. WM. OLSON .IND EUGUST OLSON are hydrauliaking on No. I bove penoh, lat Tier, Left I:ialt on Dime Crook. 3 small glants are uged. 2 giant alternately plpo of the otorburden and gravel down to within a few inohos of bedrock. This remalning fow inohes of gravel and about $1 / 2$ to 1 et. of bedrook aro then shovellod into the sluice boxeg. The third giant 19 usod in the tallings. Water is supplied. by a $6 \mathrm{ft} . \times 1 / 2 \mathrm{fte}$ ditoh, $31 / 2$ miles long. The pressure at the giants is about $30 \mathrm{pt}$. Begides thenselvos, 3 men are employed steadils When the ground 1a roady to bo shovelled in 2 or 3 extra men aro terporarily emploged.

ALBERT BOGBERG is hydraulicking on No. 2 bove Bonoh, lat Ther loft Iimit on Dime Croex. Ho pipes directly into tho flume with 1 small giant. The ground avoragos about $6 \mathrm{ft}$. to bodrock and the gravel averagos about $3 \mathrm{I} / 2$ it. In depth. Ho can only work whon there 18 bays

good water as he ruger the oxcegs water from the 0lson ditoh. This. lo dolivered at about 50 ft. prosguro: Begider himolf, I man is omployed when water ia avaliable.

SAM. B. SMITH is hyöraulioking on a left limit bonch, about 6 mileo up from the mouth of Swoopgtakeg Croek, a tributary of Peace River. Wator is supplied to ono small glant undor $15 \mathrm{ft}$. prossure from a $3 / 4 \mathrm{mll}$ altoh. The overburden and gravel are pipod off, then tho remafing fow inches of gravel and the top of bedrook io shorelled 1n. A emali wateroentage of pletinum oooure with tho 
gold. Bogldes himself, 1 man is omployed.

FRANK MoCOY is hydraulicking on the Right Tork of sweepatakes Croek, on Cla1m No: 8 about 4 miles abovo S. B. Smith and is miles from the head of the crook. He pipes directly into the hesd of at flume of two 12-ft. boxes. Tmo 3-inch glants are used, one in the pit and one in the talings. The pit is drained by a 200-et. bedrook drain. Water is supplied at about $150 \mathrm{ft}$. hogd by a $11 / 4$ mile aitch. The creek itrelf is about $5 \mathrm{mileg}$ long and has an average grado in the central portion of about $21 / 2$ per cont. The depth to bodrook aver8geg 10 f.t. The ground is all thawed. There is no overburden and very few boulaers. There ure several horizontal stroaks of olay thru the gravel. The paystreak ia aald to be about $150 \mathrm{ft}$. wide. The pay lies in the lower 2 ft. of gravel and in the top of bedrock. The bodrock is a blocky, docomposod andosite. it leat 3 ft. of this bearock is taken up in mining. About 1/2 the gold le 11ne; the othor half is composed of small nuggetg. It is valued at about \$16.40 an ounce. Nocoy started work in 1911 on wo. 9 and 10 Benoh Left Jimit, where ho worked until 1927. He then atarted proparatory work in the creek at this plaoe. He bogan actial mining ono month bofore the close of the season in 1928. In 1929 be had to gtop work in the midale of the season becaves of lack of pater. Besides himself, 2 to 4 men are emploged when water is avallable. The dietance from Hayoock is about 14 mizes. Freight ratos in summer are 6 oonts a pound.

Ho raco Porter and Salem Abraham aro hydraulicking/ on 5 Bolow Discoverg on Bear Crook, a tributary of tho wost Fork of Brokland River. Four No. 1 and No. 2 giants with 3 or $31 / 2$ inch nozzios aro asod. Tho plt is drained by a bodrook flumo and a 1000-ft. bodrook 
Sewara Peninguae re' $t$ - $t$ -

drein. 3 gients are uged alternetely in the pit and 1 in the bedrock drain below the end of tho flume. The drain at this placo makos 2 opposite right angle bonds. botween which the giant is set so as to atack the tailing over the side of the drein. The flume lo composed of three 12-foot boxos. Water 1s suppliod under a 160-foot head by a 3-mile ditch from cub creek. The depth to bocrock is from 5 to $6 \mathrm{ft}$. There is no overburden and the gravel is all thawod. The gravel is coarso with nang boulders. However, it is sala that the boulders aro less numeroug as the work progresses upgtroam. The bedrook is a partially decomposed andoste. The gold is pine with a few smell nuggets. is very little platinum occurs with the gold. The gold ig valued at about 318.05 en ounce. It lies on or near bedrock. Tho 1929 operation is in an old chennel on the left limlt of the prosent creok ohannel. The pagatroak is said to be widening to 400 et. Work was started on this operation in 1926. In 1929.64,000 sq. 1t. of bodrock, consisting of elght 80 by 100 ft. plta, wea oleanod. 2 shifts are workor. 8 men, including a cook and manager, are omployod. The average length of eeason is from 120 to 130 days. In 1928 the season was 125 days. The ditanco from Fayoock 1s about 22 m1les. Freight is hauled by dogtoam in winter and by tractor in oumor.

\section{DRIFT IINING}

CARL RYLANDTR AND OJE JORGESON drift mined for 4 monthe in the winter of 1928-1929 on No. I Below Benoh 3rd Tier, Jeft Ijimlt on D1mo cFen. The pagatroak wa sbout 3 ft. high. Boofded thomgelvod, 2 mon wero amployed.

$$
\underline{\underline{A}} \underline{\underline{N}} \underline{\underline{D}} \underline{\underline{E}} \underline{\underline{E}} \quad \underline{D} \underline{\underline{I}} \underline{\mathrm{S}} \underline{\underline{M}} \underline{R} \underline{\underline{I}} \underline{\mathrm{C}} \underline{\underline{T}}
$$

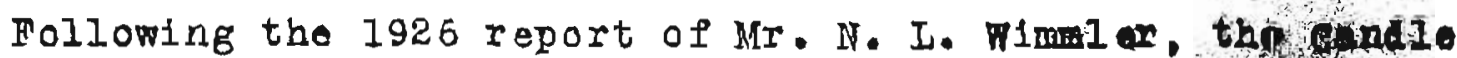
and Immachax Distrioto aro oonaldered soparatels tho both ate in the 
Falrhaven Reoording Procinct. Freight to Candle is brot directly by steamer fron seattle to Kotzebue sound, where it is lightered of $f_{\text {the }}$ bost at tho town of Keowalk, situated on a sandspit in spafarief Bry. Thence it is taken to the head of the bay and up the Keomelik River to Candle city at the mouth of Candle Creok. There 1a also a 10-day mall and passenger servioe ground Cape Prince of wales from Nome on a small gasoline-driven coastal vessel. There is a good landing fiold at Candle, and aoroplane sorvice can be had from Nomo. A fair gravel road loads out of Candie city up candle Creek about 6 miles to Datterson croek. This road has materially reduod haulage charges to the varlous operation elong the crooks. The total oost of landing Prolght at Canalo Clty $1 \mathrm{a}$ about $\$ 28.50$ a ton. It is agid that coel can bo landod at Candle City at 31.00 a ton, Inoluding the origlnal prioo of the ooal.

\section{DREDGING}

THE KEBWILIX MINING CO. opersted 1ta drodge on NO. I Bolow D1800vory on Candle Croek at the mouth of Jump Creok. Th1g drodge was originaly built and operated on the Kugruk River. It 1 a a atraight flume typo with $31 / 2$ ou. ft. buoketa and 01000 conneoted buokot lino. Power 18 suppliod by $\mathrm{c}$ two 50 H.P. Weatorn alatizlate onglnos. The dredgo averggog about. 2000 ar. gds. a day digging. The drodgo and previous operations aro degcribed on page 115 of the 1926 roport of Mr. N. I. Mimmier. Singlo $x 3 / 4$ inch pipe polate aro uoed to tham the ground. Those are sligtig upeet at the driving point, tho weter disoharging thre a 5/8 1noh holo. The eamo kind of olemps and Bleove-hemmer that were doslgned by the Hemmon Conolldated Gold Fielde, are used in driving the points. The points are set in the oenter of 16 or $18 \mathrm{ft}$. oquilateral trianglos: Fith a full hoed of water in the 81 toh. 
thero 19 about 45 pounds to the aquare inch pressure on the points. The groatost ooonoms in water consumption for this type of ground is found to be about 30 pounds to the aquare inch pressure on the points. Howovor the higher prossure thaws the ground much fastor. The points aro driven 6 to $8 \mathrm{Pt}$. Into bedrock beoause it was found that the thawed area in bedrook around each point, coned ateoply from the end of the point to tho gravel. In order to have these cones meet so that the uppor bedrock could be dug, the points have to be ariven to tho above depth. The avorage length of thaw is about l2 dage. Water 19 supplied from the 36-mile ditch of the former Candlo slaske Eydraulio Gold Mining Co. dogeribed and liated on pago 257 of J.s.G.S. Mater Supply Paper No. 314. The ground on Cande Crosic 18 ontirely frozen. The overburden, which containg much ico and is eaglig ground slu10od off with the orook water, rangea from $6 \mathrm{ft}$. thlok noar the oroek to $40 \mathrm{ft}$. thiok at the gidos of the valiey. The gravel is from 4 to $6 \mathrm{ft}$. thick. The bodrock is sohist. 3 to $4 \mathrm{ft}$. of it is dug. Tho gold is distributed all thru the gravel but Ifos mostig on and in the upper bodrook. Muob olay in the bodrook c8uses the logg of a great doal of gola. It 18 agla as much as 30 por cont. The overburdor 1a ground glulood off with the crook water and glantg go that, after it Is all thawod, the arodge diga an avorage soction of about $11 \mathrm{ft}$. The paygtreak at the mouth of Jump Crook 1 a about 700 et. W1de. Candie Creok can be drodged for about 12 miles, and poegibly for 2 miles farther. The averago widh of the oreek that oan bo drodged io about 300 ft. The dredge orew congigts of 7 mon, working in 2 ghifte. jbout 40 mon, a suporintendent and general manager aro omploged bltogother. Tagog for oommon labor are 62t oenta an hour plus board. Distillato oosts about 33 conta a gallon at the drodge. 
Tho dredgo and property had been fornerly leased and optionod by tho Golden Center ring, Inc. This lease and ontion wrs given up in 1928. The old No. $\varepsilon$ dredge was operated intermittantly in 1926 to test ground on No. 16 bove Discovery. It had previously worked the creek bed gbout $60 \mathrm{ft}$. Wide from Ho. 4 Below to No. 8 sbove Discoverv. It was too small for the work and is nov lrid up.

FYDR UUICKIIG

I. $\therefore$ SUNDGUIST operated \& smill hydraulic elevatoron No. 19 1bove Discovery fust bolow the mouth of eaterson creok. In 1929 he took out 2 pits-one 4200 an. ft. In area and the other 4500 sn. ft. Wunden. One 2 or $21 / 2$ inch nozzlo is usod in the pit and one in tho tailinga. From the elevetor three 14 xl 8 inch $12 \mathrm{ft}$. boxes are used with iron riffios. Mater is obtalnod under 90 ft. prosgure by a aitch from Pattorson Croek. Niere is kbout 7 ft. of old tailings on the ground, then about lis ft. of gravel containing horlzontal gtroaks of muck. The eravel 19 all frozen. The bedrock is schiat. IIowever, in the next cut to be mede up Patterson Crook, the bodrook is a doomponed porphyritio andesite. Besides himself, 2 men are emplojed. O. A. IIIDBERG is hydraulicking into a flumo on the lept limit bonoh channol of Patterson Crook about $1 / 4$ milo abovo sundquat. Two $21 / 2$ inch nozzles are used under about a $50 \mathrm{ft}$. hoad of water from a ditoh from Patterson Crook. The flume is la1d in a bedrock drain cut thru the rim of the channol and dumping into Fatterson creok. The ground is about $15 \mathrm{ft}$. deep, of whioh $5 \mathrm{ft}$ is gravel, the rest muck. The bedrock is gchist and porphyritic andesite. About $30,000 \mathrm{gq}$. ft. of bedrook was clouned in 1928 anó about 15,000 in 1929. Bes1der himself, 2 men are employod. 
T. P. ROUS was operating a hydraulio elovator in the early part of the in sumer of 1929 on lower Jump Creok. The ground is leased from Wo. F. Fronch. i 2 -inch nozzle was usod in tho p1t, a 3 -inoh nozzlo in the elezator and a $21 / 2$ inch nozzle in the tallings. Water is obteined from Jump Crook and 19 under a $90 \mathrm{ft}$. hood at the nozzlos. There is 16 ft. of muck and $10 \mathrm{ft.}$ of gravel. The bodrock is schist. The gold is fairly course (about "wheat" size). lio largo nuggeta oocur. lbout 10,800 sa. ft. was mined in 1929. Tho ground then beorme so poor that Rous shut down in ordor to do some prospocting. Then in oporation, one or tmo men bogideg himgelf are emplogea.

A. NORDLIID $\triangle N D$ OSCSK SWillSON are hydraulicking into a flume on No. 10 dbove Discovery on Pattergon Croek. Begldes themselves, 2 men are omploved.

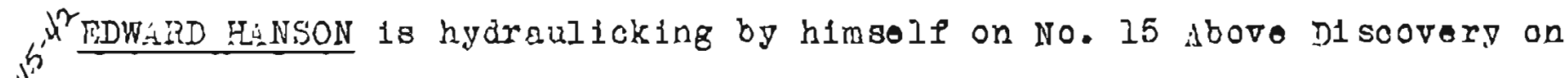
Cand le Crook.

J. LITPLF is hydraulicking by himself on Gleoler Crook.

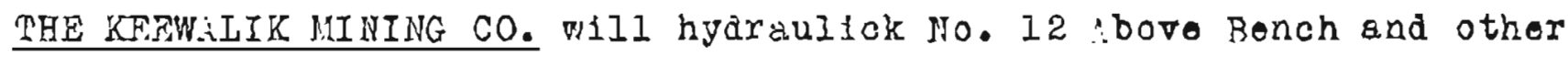
benches on the left limit of Candle Creok. They have $181 d 2800 \mathrm{ft}$. of bro-inch pipor from thoir ditoh on the right limit, sorogs tho orook to it $x^{b}$ their benches on the left Ilmit. The bodrook on this high benoh ohanael is about 100 ft. above the oreok level. There will be about 50 ft. proa sure at the nozzes. HEWRY CORFIN , ND JERRY COFRIN aro operating a hydraulio elevator on Disoovory Claim on Kugruk IRiver, gbout $1 / 2$ mile abovo tho mouth of Chleago Crook. The olevator has a 2 I/4 inoh nozzle and 11 te 16 ft. Wator 1s suppliod to 1 t by a 4-1nch Delegallo oentrifugal pump. Tho power for tisis pump is fumishod by a $35 \mathrm{~K} . \mathrm{P}$. Continental ongine. The glant in the p1t has a $13 / 4$ inch nozzlo and Is ouppliod with wator thru a 3-inoh Dolagele. oontrifugal pump by a Fordeon traotor. 
The flume is composed of three 14 -inch by 18 inch,12-ft. boxes and dumps directly into the Kugruk Piver. Mooden riffles stripper with iron are used. Whe ground is silout $12 \mathrm{ft}$. beop. is to $5 \mathrm{ft}$. is and and silt, the rest gravel. The bedrock is a blocky yellow and blue limestone The cold is frirly fine with no nuggets. It is worth about "18.00 in ounce. One pit wsis lost in the spring of 3929 by the river overfloving: it. The present pit is cbout $100 \times 60 \mathrm{ft}$. Grsoline costs sbout 21 cents a gallon landed on the herch it the month of the rugruk piver. It costs ghout 37.00 to run both engines for 10 hours. Ho men are employeo. Heviling is done by pordson tractor.

\section{DRIDP HINING}

dr. I. MCDOMALD is drift mining and prospeoting by himeolf on No. 10 above Bench, End Tier, Jeft Ilmit on Candle Crook.

\section{SHOTHLIISG II}

J. MUREFY is shoveling in by himgele on a left limit benoh opposite $s^{4^{n / 1}} 7$ above on Cinale creek.

J. PEDDIir is shovelling in by himself on a left limit bench opposito No. 8 ibove on Cindle creek.

\section{PROSPTCTING}

R. IISSOI arilled with a small crew in sugust on vuartz crook, a right limit tributary of Keewallk River.

C. R. PAPTRSON prospected on "illow Creak, a small le ft limit tributary of Cand creek above Yatterson Creok.

Wm. IT,iVITR prospooted on Gold Run croek, loft limit tributary of Keowlik River below susirtz crook. 
Seward Poningula I ort -3Q-

$\underline{I} \underline{\underline{N}} \underline{\dot{A}} \underline{\mathrm{C}} \underline{\mathrm{U}} \underline{\mathrm{K}} \quad \underline{\mathrm{D}} \underline{\mathrm{S}} \underline{\underline{T}} \underline{\underline{R}} \underline{\underline{C}} \underline{\underline{T}}$

Trelght is linded directly from steamers during the opon season sit Deering at the mouth of the Inmachuck River. A fair gravel road lekds 25 miles up this $x$ iver to the min operation of the district. There is a landing fleld $\lambda$ t Deering and aeroplane service may be had from Nome.

\section{HYDR UIICKIIG}

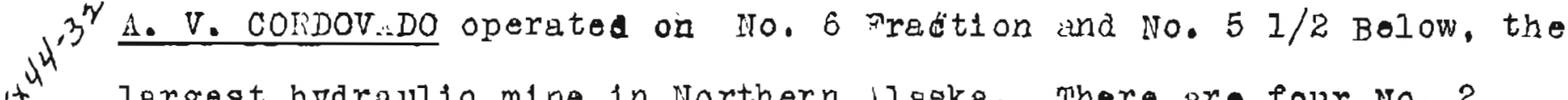
it largest hydraulio mino in Northern llaska. There aro four No. 2 gients in the pit and two ivo. I gisuts on the tallinga. The gravel is olevated about 40 et. The elevator has a 4 -inch nozzle, a 9-inch throat and $: 14 x 18$ inch door. Ten j0x48 inoh, 22 -it. boxes aro used in the Plume. Tater is Iurnished by the 40-mile ditch of the formor Pairhaven Water Co. from Imuruk Iake. S full deacription of this aitch is givon on page 257 of U.S.G.S. We.ter suppig papor No. 314. The head on the giants is $360 \mathrm{ft}$. The setunl head from the ditch $1 \mathrm{~s} 560 \mathrm{ft}$, but as the pipes are too werk to stand this smount, it is cut down $200 \mathrm{ft}$. The depth to bodrook is from 20 to $25 \mathrm{ft}$. The ground is thawed and all gravel. The bedrock 1s sohist. The gold $110 \mathrm{~g}$ in the lower $I$ ft. of gravel and in the uppor $3 \mathrm{ft}$. of bodrook. The gold $1 \mathrm{~g}$ fino in the prosent pit. In 1928, about 110,000 sa. It. of bodrook Weg cleaned and in 1929 about 140,000 gq. ft. Begldeg himeris, 22 men aro emploged, diatributed as follows:- 10 men, inoluding foreman, in eit; 7 mon on ditch, 2 men on penstock, ono cook and helpor and one traotor ariver.

\section{HOOGENDORN}

ul D. H. No. 5 Below Hannum. Throe 3 -inch nozzles are used altornately in the pit and one 3-1nch nozzlo in the tailings. Seven 14xib 1noh-12 it. 
Soward Peningula $R$ jrt -32-

boxes are used th the flume. The ground is a ingth channel paralleling the Inmachuck River. The sverago dopth is $15 \mathrm{ft.}$ It is all thawed. Mang boulders ocour and the gravel is fairly coorse. The bedrock is schist. Water is obtalned from idams lake thru a 2 -mile ditch and a I/2 rile plpe lino. The pregsure hoad is about $250 \mathrm{ft}$. Besides himself, 3 men are employed.

\section{SHOVELIIHG IN}

I. E. BFNSON LND JOHN DOBURR put in a dam and shovalled in on Abovo Discovery on Cunningham Croek during 3 montha of the sumrner. Benson will prospoot here in winter of 1929-1930. It is sald that the 801d recoverod was in the form of a new black alloy of gold and iron. CHAS. NICHOL is ground slulcing and shovoling in by himegle on Cunningham Croek.

\section{IROSPECIIIIG}

THE IMLACHUK SUBLAVA MINIHG SO. (H. I. Stull, progident and gonoral manizer) is prospecting the old high channel under the lava on the Iucky

Dutohman Bench opposite No. 3 Below Pinnell and on the left limit of the Inmechuck River. Mat of the work is done in the winter. Beoldes himself 4 mon are employod. An Ingermoll-Rand s. 49 Jackhamer $1 \mathrm{a}$ usod in sinking thru tho lava. . Ir is supplied by an Ingorgoll-Rand compressor

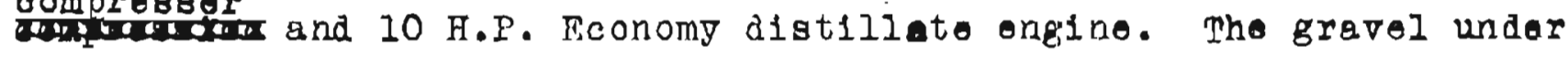
the lave is from 6 to 16 ft. thick. It 1o all. Irozen. The bedrook is schist. 5 shafte, ranging from 203 to 132 it. deep, and one inoline $380 \mathrm{ft}$. long, have boen sunk. It cost about $\$ 30.00$ a foot to eink ghafts and 35.00 a foot to gink 1nclinos. Wroight oosta $\$ 15.00$ a ton Irom Dooring. JOFN Do BUHR w1ll prospect under the lava in the winter of 1989-1930 on a rieht limlt bonoh opposite the Globo Asgoolation (Trieg' old 
oamp). He hag worked here for the last 4 years.

$$
\underline{E} \underline{O} \underline{U} \underline{G} \underline{i} \underline{O} \underline{\mathrm{K}} \quad \underline{\mathrm{D}} \underline{\mathrm{S}} \underline{\underline{T}} \underline{\underline{P}} \underline{\underline{\mathrm{C}}} \underline{\underline{T}}
$$

Froight rates, trensportation facilitios, doscription of tho Eougarok River valley, otc. have been fully given on pages 117 to 120 of the 1926 report of I.r. M. I. Mimmler and will not bo gone into hero. The frelght rate, due to tractor haulage, is now in sumer 150.00 a ton from Nome to Psilor P.O. From frome to shelton, the rato is 30.00 a ton. From shelton to Dahi creek the rate 1330.00 a ton. seroplane conveyanoe nay now be had from None to the mouth of Fonry rreek about 2 miles below Paylor …0.

HYDR UUL TCKING

E. I. WEIIS, R. P. WFIS S, CHLS. J. NEISON IND ISADORE FIX are hydraulicking into a flume on Irerrit Gulch, a small lept limit tribatary of Henry Croek nonr its mouth. Two No. 2 giantg with 3-1noh nozzes are used 1 n the pit, and one No. I giant with a 3-inch nozzlo is use in the tailings. The flume is mado up of four 14x24-inoh 12 ft. boxes with iron stripped wooden riffles. Wator lo bbtalned by a $31 / 2$ mile section from lillian crook, of the ditch of the formor Teyjor Crook Ditch $C_{0}$. This ditoh is liated and desoribed on pago 258 of the U.S.G.S. Wrter Supply Paper No. 314. From the present ond of the ditch a 1500 ft. pipe line,gracuatod from 20 inches down to 12 inches, loads to the giants. The ground averagea about $12 \mathrm{ft}$. to bodrock. The gravel is $5 \mathrm{pt}$. thick and $1 \mathrm{~g}$ frozen. The $7 \mathrm{ft}$ above $1 \mathrm{~s}$ vogotable muck and lae. The gravel has mang inclualong and layorg of mack and w11low in it. There aro many welz-water-worn bouldore,wolghing 50 to 100 pounds, mostly of ousta, in tho gravel. The rost of the gravel is ma inly composoa of well water-worn, rather small pobbles of 
Soward Peningula Repi-v

schist with oocesionel enguler blooks of the underlying bedrock. Trie bodrook is a partilly decomposed andesitic rock. Which weethers at the top of bedrock into smell, sharp-angled oubes. 2 or 3 ft. of this bodrock is minod. The gold is found in the lower $j \mathrm{ft}$ of gravel and in the uppor bearock. The gold varies from fairly coarse ("pumpkin seed" oizo) to verg fine. Tew nuggets are found. The rold is valuod at ijp 7.95 an ounce. This doposit is undoubtedly formod by a small stroam (larger, however, then the present trioklo in Merrit Guloh) outting a high channel of tho Kougarok River. The gold content comes from a reconcentration of this channel. The incluglong of willowg and muak in the gravel mig reprosent slidos from the chennel. A vory singular ocourence in these gravels, among musk-ox, horse, b1s on and manmoth bones. some in in ll most perfect state of preservation--are stones worked bJ man. These oonsist of flat sohist bouldora about $18 \times 22 \times 6$ incher with holes bored in one end; also schist gtoneg about $12 \times 6 \times 5$ inches with oingle or double grooves out around them. These stonos were ovidently anchor stones and weightg for skin tents. They ooour Prom bodrock to the top of gravel. Tho very anoient, I do not oonsider them contemporaneous with the bones, but to have boen mixed with thom by slides. Work mas started hore in 1927 and $1250 \mathrm{gq}$. ft. of bedrook cloaned. In 1928,8000 aq. It. of bedrook wa dioaned and In 1929. 9600 gq. ft. Besides 2 of the owners. 2 other mon are omploged in this oporation.

EMIL IAUEII -ND HECTOR LAURIN hydraulioked into a flume on Meokl1n

Creak about 2 miles above tho mouth on Ho. 8 Above Disooverg. 2 nozzles are used in the pit and one in the tailingo. Water lo obtainod by a $31 / 2$ milo ditob under about a 150 ft. head. The gold 1a fa1rig coarse. 3esides themselver; 2 mon are employed. 
NICK NICON LND GRORGE BODIS are hydraulicking into s flume on Dick $\lambda^{8}$ Creek at its confluenco with Bryun Creek. There is one nozzle in the pit. Mater is obtained by 4 l $1 / 2$ mile iltch end is delivered under a 35 ft. heud. The tailings ire stecked by grant mechenlcal atacker powered by a small grisoline engine. There is $8 \mathrm{ft}$. of muck and $3 \mathrm{l} / 2$ ft. of gravel in the creek. The ground is lossed from the Inspiration Gold lining Co. of Pittsbarg. Besides themeelves, ono man is omployed.

\section{SHOVELLILG IN}

BARRY GAVIN is ground sluicing end shovelling in by himgelf on Harris Creek about 1 mile from the mouth.

B. R. AHRSilis is ground sluicing and shoveling in by himgelf on on Farrig Crook rbout $3 / 4$ mile from its mouth.

JOFON DONOVAN grouna sluiced and shovelled in by himeolf on willow $s^{\prime}$ $+44^{-6}$ (or Masoot) Guzch.

GTORG about $1 / 2$ mile below Taglor Croek.

JUD. CIIDFSTFR bulit a aitob and ground slulced and rooked by himeolf on a right limit bench of the Kougarok River opposito Taylor crook. ALRRED CARTY ..ND JOHN KANARI shovelled in on No. 5 Abovo Dleoovorg on Dahl Creek. Thoovorburden is f1ret ground slulood and plpod off, thon the gravel and upper bodrock is shovellod into boxos. For ground sluicing and plping a $21 / 2$ 1nch nozzlo 1 used, attachod to a oanvag hose which 18 itsolf attached to a short pipeline. Water io obtrainod from Dehl Crook by a $1 \times 4$ ft., 1 I/2 mile ditoh under 20 ft. head. There is 20 to $40 \mathrm{ft}$. of orerburden congisting of muck and 100, and 6 ft. of very f1no gravel. There 18 a clay bedrock. The deposit io all frozen. The gold 11 es on the bodrook and for about 2 ft. In 1 t. The gold 18 fairly oogrse. It 18 worth \$19.15 an ounoo. Bosidos 
Soward Poningala Report

themgelves, one man is employed. 14k th Dahl Creek.

DR. Z. L. GRAVEN ground sluiced and shovelled in by himsele on wonder Gulch. There is about 14 st. of muck and 1 ce and 3 to 4 ft. of fino gravel. The bedrock is schist. The pajstroak is about 60 ft. W1de. Tho gola occurs ell thru tho grapel but mostly on bedrock. 1 bout $1 / 2$ tho gold is small nuggots, the rest very coarge (about rrock galtn s120). $2400 \mathrm{fti}$ of bedrock was cloanod in 1929. JERRY SUIJIVAN shovellod in by hImself on No. 3 Abovo D1 soorer on q Humbolt Croek, a largo left limit tributary of Goodhope R1ror. claim $\left(4+44^{\prime}\right.$ ground ig about 9 ft. doep and 18 gaid to carry very good values.

\section{PROSYTCTTNG}

THE HENRY CREFK GOLD DREDGING CO. prospooted with 5 men and a 4-1noh hand drill on lower Heary Creek. If the ground proves up, it is the 1atention of the compeny to move drodge of the Bohring Dredging Corp. Prom the mouth of Arlzone Crook and drodgo Kenry Crook.5 mon woro amployod. W. H. SUKSDORF arilled for gold and tin on Humbolt crook 1 itb 6 mon and a light 5-inoh gasoline orill. Drilling was from about 5 miles bolow to 5 miles above Ferndal creok. Tho ground 19 thawed and about 18 ft. doop. There 19 only about 2 ft. of muck, the reat graval. Tho pay seeme to be in the lower 4 or 5 ft. of gravel. Tho bodrook 18 sohist. Tho crook valiey averagos about $400 \mathrm{ft}$. wide. If th1s prospeoting is gatigfactory, a dreage will be ingtalled on this oreok. It 1s oloimed that the ground oarries about 3 poundo of aeve1terite to tho oubio gard. Besider bimeele, 8 men were omployed: 
Seward Peningula Roj it

HARVEY GRINT END ISADOFE MIX bought out Tad. and Rasmus Jensen on Tagle Draw, a small right limit tributarg of cof foe creok, and prospeoted by shovelling in. Thare is about $22 \mathrm{ft}$. of muck and $4 \mathrm{ft}$. of grenel. Water lo obtalnod by a $3 / 4$ mile "piok up" ditch from coffeo Dome. The partners intend sterting on a production busis in 1930. CHAS.ROOSEVELT (OLSON) dug a ditch and progpooted by himself at the mouth of Faglo Draw on No. 4 ibore Bassottis. The claim is optioned from Paul Rasmua.

Vm. SINHOLD prospocted in the winter of 1928-I929 on la er Fomostake Crook (Jumper Benoh). Sinhold. T. $p r i l l$ er and Jorry sulliven intend opening up a hydraulio oporation here in the sumrer of 1930. They startod the dnl and ditch in the fall of 1929. Theg own 7 oreek claime and 8 benoh clatins on this creok. J.R. SLOAN prospooted in the winter of 1928-1929 on Moborg Guloh, a small loft limit tributarg of Kougarok River opposite henry Croek.

$\underline{I} \underline{\mathrm{O}} \underline{\mathrm{N}} \underline{\mathrm{C}} \underline{\mathrm{R}} \underline{\mathrm{E}} \underline{\mathrm{E}} \underline{\underline{K}}-\underline{A} \underline{M} \underline{\mathrm{E}} \underline{\mathrm{R}} \underline{\mathrm{C}} \underline{\underline{N}} \underline{\mathrm{N}} \underline{\mathrm{C}} \underline{\mathrm{R}} \underline{\mathrm{E}} \underline{\mathrm{E}} \underline{\mathrm{D} I \mathrm{~S} T R I C T}$ HYDR:ULICKING

THE AMERIC:IN CREFE MINIIG CO. (Barnoy Rolando, gonoral managor) 10 hydreulicking into a flume about 12 miles up from the mouth of Amerloan Crook, a right limit tributary of the N1ukluk River abovo Cagadepaga River. One 3-inch nozzlo is used in the pit and one $21 / 2$ inch noralo In the tallinga. Water is obtained by a 5-milo ditoh and undor a 115 ft. hoad. 1929 was the first soason's work. Tho ditch and proparatorg work was bogun in 1926. Freight ig hauled from Iron crook 8 mlleg by traotor. Besidos the managor, 3 men aro employed. ROBT. B. BENSON 19 hydraullaking by himeolf into a flume on Reneon Creek, a small right limit tributary of Iron croek. 
GR:NT LIIBLIN, GEORG LAIBLIN AND $A$. V. CORDOV.DO are Evound slulcing and shovelling in on Dome Crook (hoad of Iron Creok) on to. 3 :bove Discovery and about $3 / 4$ milo wbove tho onnyon. Water 18 furnighed by a $1 / 2$ mile ditoh. The ground is 6 to 7 ft. deop in the creek and 12 ft. doep on the bonoher. It is thuwed and all gravel. The gravel is fairly fine, with bouldero not over 18 inches in dismeter. The bedrock is sohist, 6 to ' 8 inchos of which are mined. The gold oocurs in the lower 2 or $3 \mathrm{ft}$. of tho graval and in tho top part of tho bod-

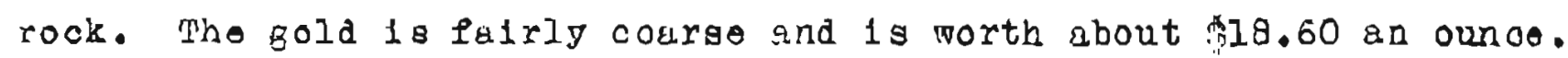
Work was started on July 24, 1929 and stoppea on september 8, 1929. Besidos on of the partners, one man was omployed. STINLEY HORION shovelled in by himself on NO. 4 Above Disoovery on Iron Creok. The ground is rabout $10 \mathrm{ft}$. deop and thamed. The pag $1 \mathrm{a}$ in the lower 2 or $3 \mathrm{ft}$ of grovel.

\section{PROSP ECTING}

COLLLN GRIFIN prospectod on Shorrotto Crook and around Nt.Bendolobon. $53^{, 40}$

$$
\underline{\underline{O}} \underline{R} \underline{\mathrm{T}} \quad \underline{\mathrm{C}} \underline{\mathrm{A}} \underline{\mathrm{R}} \underline{\mathrm{E}} \underline{\mathrm{N}} \underline{\mathrm{C}} \underline{\mathrm{E}} \quad \underline{\mathrm{D}} \underline{\underline{\mathrm{S}}} \underline{\underline{T}} \underline{\mathrm{R}} \underline{\underline{\mathrm{C}}} \underline{\mathrm{T}}
$$

The pleoorg of the Port Clarenoo Distriot fall natarally Intwo two divisione-.-those in whiob the primery objeot is the reoovery of gold and those in which the primary objoct 1 s the recovory of tin. There la also oomo lode mining whioh will be doopfibod ooparately. Wages in the ditrict are $\$ 6.50$ a day and board

DIVISION 1 - GOLD PI:CERS

\section{DREDGING}

N. B. THEET 1s moring tho old Sunsot Crook Drodge from soneot osook to Dose Croek. The dredgo hag been diamantled and partialig eored part

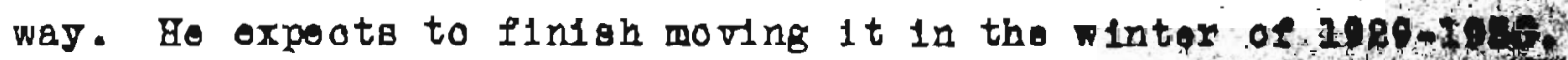


HYDR:UUIICKII!G

N. B. TileET hydraullcked on Coyote Creek. Water wes obtained by a $\psi^{+} b^{x^{3}} 1 / 2$ mile ditch from tine creek. Besides himsols, 3 men are employed. SHOVTILIIIG IN

'EiNS IHORSON shovellod In on Gold Run Creek. Besidos himsolf 3 men $\left.+4 t^{3^{20}}\right)$ are employod. OLE MARTIHSON shovell ed in by himself on Gold Run Creek. GENNING JOHNSON shovelled in by himself on Gold Run Croek. FISHER B.IJRIDGE shovelled in on Windy Croek. Bosiñes htmself, ono ${ }_{4}+3^{b^{3}}$ man was employed.

IROSYECPIIG

B. K. POSILERHWITT MND FLRRY DOBSON prospedted and ghovelled in on Budd and Burko Crooks.
$4^{1} \cdot 81$
$43-19$

\section{DIVISION 2 - TIN PLACERS}

\section{SHOVTLLING IN}

GEORGF WiLDHEIM shovelied into cars which were then run to tho aluico $r^{43^{3^{-k}}}$ boxes and dumped. The operation is gituated on Goodwin Guloh, a tributary of Goodwin Creok which runs in to Iopp Iagoon fugt oagt of Lsgoon Creok. The ground is leaged from H. J. Chrigtanaen and Thor. Christengen. Flvo - 16 Inch boxes are used. Wator 19 pomped from a sump by a $25 \mathrm{H} . \mathrm{P}$. Fairbenks-Morso d1080l engine. There 18 algo a I mile Aitch delivoring weter at a $50 \mathrm{ft}$ head which 1 a uod for ground sluiolng whon wator is availablo from raing. Tho dppth to bedrook $1 \mathrm{~g} 4$ to $5 \mathrm{ft}$. The gravel oontaing mang boulderg up to 18 inches in demor demoter and is all thawod. Tho bodrook 18 a blookg IImegtone. The easiterito genorally oocurs as a coarso land, tho pleoes up to 6 and 8 inobos in diameter are froquentig found. espeoially towards tho hoad of tho guloh. 
Work was started here in 1926. That production to the season of 1929 was sbout 71 tons of concentrateg. The production is 1928 was 34 tons and in 1929 sbout 33 tons. Tho clemned concontrates sssey sbout 72 perroent tin. Besldes himself, 13 mon aro omployed. This operation proably will not list orer another season. $\quad$ more detalled dogoription of the creak is given on page 126 of the 1926 report of Mr. M. I. Wimmlor.

H. J. CRRISIRNSEN .IND THOS. CHRISTENSEN shovelled in on Goodwin Gulch above Weldhelm. The ground is about 5 tt. deep and all thawod. There is no overburden. Water is obtelned from a sump. The ground ia suid to run about 45 pounds of cagolterite to the ouble Jard. About 2 more seasons "ork is left on this ground. No men are employed. DUNCAN MoIFiN shovelied in on Cape Crook. This 1 a a mall gulch running down from Barteli's North star Lodo oagt of rin city. Six 12 Inoh boxes are used. Water 19 ploked up from the oreek. Tho ground 1. 3 to 4 ft. doep ana all thewed. Thore 1 s no overburaten. Tho bodrock is limestione, in some plaoes sohiotose. There are fow boulders in the gravel. The oagaitorite ooours as a coargo sand. $41 / 2$ tong wore mined in 1928 and about $61 / 2$ tons in 1929. About 2250 sq. tt. of bodrock was olegnod. About 5 segsong work ig loft for this operation. Bogides himsolt, one man is employed.

\section{PROSPECTING}

3. IE. RIJI IVD R. H. KIII have beon prospooting and tosting ground by ahoreling in on Firat Chance Gulch, a tributary of cape Creek, and on Josephine Guloh. In the season of 1930, they vxpeot to build a I mile ditoh from First chanco Gulch and hydraulio on Josephine Guloh. M. A. DOMINGOS prospooted and did ageosement no rle on Iron creok. a tributary of Suttor crook, and on suttor croek. 
Seward Poningula Report

$-41-$

T. A. ZTTERSON had 2 men prospecting sind doing assessment work on $\mathrm{k}^{+\mathrm{H}^{3}}$ Tin Crook and Capo Crook.

UNGALIK RIVER - NUL:AIO DISTRICT

There hag boon no mining done in this district for several yours. The proven dredging ground on Bonanzas crook, and, at the mouth of the crook, on the Ungal1k 21 ter, hag been patented and let lie without an g more work done on it. This region hag groat potentialities for dredging and should be thoroly prospected. A more detailed desorption is given on page $128-129$ of the 1926 report of Mr. N. I. Wimpier.

41 